\title{
TV/Series
}

$4 \mid 2013$

Écho et reprise dans les séries télévisées (II) : Re-

présentations -- enjeux socio-culturels, politiques et

idéologiques de la reprise

\section{Through The Wire: The Avon Barksdale Story}

\section{Sébastien Lefait}

\section{OpenEdition}

\section{Journals}

Electronic version

URL: http://journals.openedition.org/tvseries/746

DOI: $10.4000 /$ tvseries.746

ISSN: 2266-0909

Publisher

GRIC - Groupe de recherche Identités et Cultures

Electronic reference

Sébastien Lefait, «Through The Wire: The Avon Barksdale Story», TV/Series [Online], 4 | 2013, Online since 15 December 2013, connection on 20 April 2019. URL : http://journals.openedition.org/ tvseries/746; DOI : 10.4000/tvseries.746

\section{(c) (i) (3)}

TV/Series est mis à disposition selon les termes de la licence Creative Commons Attribution - Pas d'Utilisation Commerciale - Pas de Modification 4.0 International. 


\section{Through The Wire: The Avon Barksdale Story}

Released exclusively on DVD in 2010, The Avon Barksdale Story is the first and only instalment so far of a series of docudramas called Baltimore Chronicles: Legends of the Unwired. As its title indicates, the film claims to tell the real events in the life of Baltimore drug kingpin Nathan "Bodie" Barksdale in order to expose his near namesake from HBO's The Wire (2002-2008), Avon Barksdale, as a fictional persona. Structured around an interview of the real Barksdale by the actor impersonating him in the series, The Avon Barksdale Story presents itself as a corrigendum or as a right of reply. This so-called critical reading thus aims to debunk The Wire as a distortive rewriting of events. The film's title, however, paradoxically acknowledges that it tells and perpetuates the legend of Avon, Nathan Barksdale's fictional counterpart, despite the fact Nathan declares he always resented the nickname "Avon”. Besides, even though The Avon Barksdale Story sets out to restore the reputation of the historical gangster by seeing through The Wire, it also borrows, at regular intervals, the typical style of David Simon's program. Consequently, while the docudrama claims to tell the real stories from which The Wire is freely inspired, it is itself loosely based on the fictional stories told in the show.

Through a comparative analysis of sequences from The Avon Barksdale Story and extracts from The Wire, this paper purports to identify a specific type of TV series derivative, a hybrid form of remake I suggest to call the "alternative make," and to investigate its role as an analytical instrument. As a matter of fact, the mechanics of this "counter-Wire" indirectly informs the nature of David Simon's study of social reality through the narration of semi-imaginary life stories, and The Wire's unique approach to fact through fiction.

$\mathrm{R}$ eleased exclusively on DVD in 2010, The Avon Barksdale Story is the first and only instalment so far of a series of docudramas called Baltimore Chronicles: Legends of the Unwired ${ }^{1}$. As its title indicates, the film claims to tell the real events in the life of Baltimore drug kingpin Nathan "Bodie" Barksdale to expose his near namesake from The Wire (HBO, 2002-08), Avon Barksdale, as a fictional persona. To this end, a voice-over narrator, Troy May, tells the audience Barksdale's real story. Structured around an interview of Barksdale by the actor impersonating him in the series, Wood Harris, The Avon Barksdale Story presents itself as a corrigendum or as a right of reply. This so-called critical reading aims to debunk The Wire as a distortive rewriting of events.

The film's title, however, paradoxically acknowledges that it perpetuates the legend of Avon, Nathan Barksdale's fictional counterpart, despite the fact that Nathan declares he always resented that his friends should use his middle name "Avon", as he preferred the nickname "Bodie2". Besides, even though the docudrama shows Barksdale taking offence at the contents of The Wire, he seems to have

1 The documentary was directed by Drew Berry, Bruce Brown, and Kenny Jackson. A second instalment, focusing on the real person behind The Wire's Marlo Stanfield, dealer Marlow Bates, seems to be in the works, but has no release date yet.

${ }_{2}^{2}$ In The Avon Barksdale Story, he explains that his friends mocked his middle name because his mother chose it in reference to Avon cosmetics, which is why he later responded exclusively to his first name "Nathan", or to his street name "Bodie". 
changed his mind about it over the years. In his book about the series, Rafael Alvarez, who worked as a writer and story editor on The Wire, relates that Nathan Barksdale made a cameo appearance in Season 1 episode $7^{3}$. This suggests that Barksdale's dislike of his portrayal in the show, which led him to the idea for The Avon Barksdale Story, came as an afterthought. Additionally, Alvarez claims the character only borrows Barksdale's name 4 . To him, the real gangster did not inspire the character of Avon. He describes Barksdale and his associate Stringer Bell in The Wire as "fictional composites5". Alvarez adds that the character of Barksdale is closer to a 20-year-old dealer named Warren Boardly than it is to Nathan ${ }^{6}$. Finally, even though The Avon Barksdale Story sets out to restore the reputation of the historical gangster by seeing through The Wire, it also borrows the typical style of David Simon's program regularly. Consequently, while the docudrama claims to tell the real stories behind The Wire, it is itself loosely based on the fictional stories told in the show.

For those reasons, The Avon Barksdale Story initiates a specific brand of TV series derivative. It is a hybrid form of remake, which I suggest to call the "alternative make". Its main point is to re-use the style of the series to tell a story that contradicts the lies David Simon allegedly disseminated in it, which suggests that, in Barksdale's opinion, Simon's claim to the truth in The Wire is a mere stance. To this end, Barksdale and executive producer Kenneth Antonio Jackson, who used to conduct the same activity as Barksdale, although in another part of Baltimore, hired director Bruce Brown and

\footnotetext{
3 Alvarez mentions this anecdote in the "Cameos and stunt casting" section of his book. Nathan "Bodie" Barksdale was cast as a recovering addict who refuses to sign junkie Johnny's court slip in Season 1, episode 7: "Barksdale had only recently been released from the Maryland Correctional Institution in Jessup when this episode was filmed." Rafael Alvarez, The Wire: Truth Be Told, Edinburgh, Canongate, 2010, p. 461.

4 "Although no specific character in The Wire was modeled on [Barksdale], Simon and Burns were familiar with his status as a drug trafficker in the 1980 s and used both his surname and street moniker in homage.” Alvarez, p. 462. It is unclear which nickname Alvarez is referring to here. In fact, David Simon searched legal archives for Barksdale's name, and found "that in all his police documents, arrest records, and court papers Barksdale is referred to only as 'Nathan Barksdale'; in some cases the documents even include the abbreviation 'NMN' - 'no middle name.” Jeffrey Anderson, "Last Word: Nathan 'Bodie' Barksdale and Kenny Jackson tell their versions of Baltimore's street life in The Baltimore Chronicles: Legends of the Unwired", Baltimore City Paper, April $29^{\text {th }}$ 2009 (http://www2.citypaper.com/news/story.asp?id=17966\&p=4, consulted August $3^{\text {rd }}$ 2012). As a result, Simon may have considered "Avon" to be Barksdale's nickname. Nevertheless, the gangster's actual nickname, "Bodie", is also used to name a character in The Wire, Bodie Broadus. In fact, Simon used both Barksdale's middle name and nickname in the series, yet for two different characters.

${ }^{5}$ Alvarez, p. 50.

6 "Waged throughout the summer of 1986 by a 20-year-old dealer named Warren Boardly, against brothers Alan and Spencer Downer, the battle left seven dead and twice as many wounded before Boardley had control of the terrace and Poe. [...] Avon Barksdale bears more than a passing resemblance to Warren Boardley.” Ibid.
} 
producer/writer Drew Berry7. To restore the reputation of Barksdale and Jackson, those employees scatter black and white sequences imitating the style of The Wire among documentary parts about the life of the Baltimore drug lord 8 .

The poor quality and simplistic mimicry that characterise the Wire-like sequences in the docudrama, however, are unwillingly in clear contrast with the original series. As a result, one can use The Avon Barksdale Story as an analytical pendant to The Wire. Because of its many paradoxes, Barksdale's strategy endows the film he commissioned with a mise-en-abyme pattern. By attempting to look like The Wire, although with a blatant lack of nuance, The Avon Barksdale Story reveals how subtly David Simon's series bases fiction on real situations. The docudrama thus goes out of its creators' hands, to become a documentary about The Wire rather than about Avon Barksdale. It works as a distortive mirror against which the show can be studied. The mechanics of this "counter-Wire" indirectly inform the nature of David Simon's study of social reality through the narration of semi-imaginary life stories. The Avon Barksdale Story misunderstands Simon's fictional perspective on reality. The same goes for his use of composite characters rather than actual people, and for his utilisation of archetypes rather than individuals. This lack of perspicacity motivates Barksdale's resentment about his namesake in the show. The sequences that feature Barksdale next to Wood Harris to emphasise how physically different they look from each other express Nathan's bitterness. To prove these arguments, I propose to use contrastive examples taken from The Avon Barksdale Story and from The Wire. I will analyse them to establish what their comparative analysis teaches about the unique form of documentary fiction invented by David Simon. To reach that point, I will successively focus on the problematic nature of The Avon Barksdale Story and on its specificities as an alternative make, to finally return to The Wire and characterise its approach of fact through fiction.

\section{The problematic nature of The Avon Barksdale Story}

A true documentary approach, or mere documentary realism?

Its expository tone characterises The Avon Barksdale Story. The film advertises its aim to debunk the story of Avon Barksdale told in The Wire. Its documentary form is a consequence of this general purpose. The documentary approach dialectically seeks to incarnate

${ }^{7}$ For more details about the origins of the docudrama, see Anderson.

${ }^{8}$ Using black and white allows the spectators to tell the documentary moments from the fictional ones, but also forbids them to mistake the fictional sequences embedded in the documentary from actual sequences in The Wire. 
facts, and to present The Wire as pure fiction. To strengthen the antithesis between documentarism and fictionalism, the creators of The Avon Barksdale Story include real documents. Photographs of the real Barksdale as a kid appear alongside newspaper clippings of articles written by David Simon in his days as a journalist for the Baltimore Sun. The news documents purport to bring evidence that Simon betrayed his objectivity oath as a journalist when he used the names of real people for the characters in his series. In similar vein, the docudrama includes TV news extracts shot in the 80s, showing the police intervening in the Baltimore projects. By comparison, the vintage quality of the images enhances the artificiality of The Wire's shooting style, to qualify the series as realistic rather than real. As a result, the hybridity of The Avon Barksdale Story generates uncertainty regarding its own form.

\section{Documentary? Drama-doc? Docudrama?}

The credit sequence of The Avon Barksdale Story is ambiguous in many respects. The terms it features seesaw across the divide between documentary and fiction. As a result, the film is uneasy to classify. It defines itself as a "docudrama [...] based on a true story", whose "main characters are real". In their authoritative work on the topic, Jane Roscoe and Craig Hight define the documentary drama in the following terms:

Documentary drama tends to use an invented sequence of events and individuals to illustrate features of real historical events and issues. This form does not necessarily conform to a realist narrative. If documentary elements are presented they may actively disrupt narrative, for example by being presented non-naturalistically. In this form, "documentary" is just as likely to refer to style as to content 9 .

This definition of a now full-fledged television genre attests that the authors of The Avon Barksdale Story use specific terminology inaccurately. If the purpose of the film is to provide its spectators with documentary evidence correcting the falsehoods found in The Wire, it is awkward to declare it features "characters", even while paradoxically labelling them as "real". Proclaiming that the movie, although advertised as "unwired", narrates the lives of "legends", is equally clumsy.

The docudrama brand-name epitomises those inconsistencies. As Roscoe and Hight's definition shows, the docudrama label means The Avon Barksdale Story delivers a fictionalised version of history. Given the authors' intention to present the contents of the film as true, it would have been more sensible of them to call it a drama-

9 Craig Hight and Jane Roscoe, Faking It: Mock-documentary and the Subversion of Factuality, Manchester, Manchester University Press, 2001, p. 43. 
documentary rather than a docudrama. In fact, according to Roscoe and Hight:

Drama-documentary is best described as the form that attempts to stay closest to the actual historical events or persons. It follows the sequences of events from a real historical occurrence or situation. The perceived closeness between their presentation and the actual events underpins this version. This form uses drama to overcome any gaps in the narrative, and is intended to provoke debate about significant events ${ }^{10}$.

On account of a still fluctuating terminology ${ }^{11}$, Brown and Berry's effort to categorise their film may just achieve the effect opposite to the one Barksdale sought for. In any case, it reveals the true incentive for making The Avon Barksdale Story. Identifying the film as a "docudrama" implies that its goal is to invent a story to contradict another invented story, and to make this alternative version pass for real. That the authors display some hesitation when it comes to classifying their work discloses their ambivalent attitude to documentary objectivity. Correlatively, some of the film's sequences confirm that the filmmakers use documentary aesthetics primarily for the sake of realism. For instance, some documents inserted in the film show gangsters with blurred faces. The technique depicts them as real people rather than proving them different from their counterparts in The Wire. Additionally, the voice-over remark that Nathan Barksdale had a "disturbingly unbelievable" life uses the cliché according to which fact is sometimes stranger than fiction. Conjuring up the formula, the authors try to account for the obvious signs of tampering with reality that inevitably show through on numerous occasions in their film.

\section{Why remake Barksdale’s life}

Rather than merely narrativising a true life story, however, the film elicits a constant tendency to rewriting. Some of the sequences thus generate the impression that it has something to promote beyond the notion that Barksdale is not the gangster viewers may think he is. A particular moment divulges that the film is essentially promotional. It includes views of the city of Baltimore chosen to illustrate the possibility of living a fine life there. The sequence contradicts the gloomy atmosphere of violence, poverty and danger The Wire conveys:

VOICE-OVER NARRATOR. Barksdale grew up in Baltimore, not the Baltimore associated with the famed inner harbour. Visitors to charm

\footnotetext{
${ }^{10}$ Ibid.

${ }^{11}$ Concerning the ambiguity of the terms, Roscoe and Hight rightly specify that, although they "each point to quite different historical trajectories of production, [...] common usage seems to reinforce their interchangeability." Ibid.
} 
city are impressed with all it has to offer. In the non-tourist areas, it's a healthy mix of middle and upper income neighbourhoods. Sometimes those neighbourhoods are only a few blocks from areas in which Barksdale was more familiar.

The commentary spoken over the pictures is full of positive epithets. As a result, the sequence sounds and looks like an advertisement. Supposedly, the bad publicity from the show made such a rehabilitating sequence necessary ${ }^{12}$.

The desire to soothe the harsh realism that characterises the series even extends to more narrative sequences, such as the "pizza" anecdote. In it, Barksdale explains how he and his crew would scare the cops away by dropping sewer lids from the $14^{\text {th }}$ floor of buildings surrounding the area where they dealt drugs. Rather than focusing on the potential danger of the action, Barksdale insists on the noise produced by the lid hitting the cement. The voice-over narrator further mitigates the violence of the deterrent by presenting it as "the delivery of pizzas". This was, the voice adds, an "innovative way [for Barksdale] to defend his money-making turf".

In similar vein, The Avon Barksdale Story delivers the tale of a good child whom his environment corrupted. In its first moments, it devotes a documentary sequence to the riots of '68 and to the subsequent construction of the rough projects in Baltimore. The scene establishes the historical and social context of racism and unrest that supposedly spawned the gangster in Barksdale. It toys with the notion of social or environmental determinism, to present the criminal mind as the product of a segregated area. This perspective seeks to imitate a similar one found in The Wire. Simon's series is rightly acclaimed for its subtle analysis of the social sources of drug-related violence ${ }^{13}$. The Avon Barksdale Story, however, clearly lacks the nuance and critical hindsight of the original, as well as its ability, despite its fictional status, to generate an objective perspective on current societies.

The same is true for the sequences in which the film narrates how Barksdale became involved in the drug dealing "game" as a kid because he needed money. In those moments, Barksdale exploits the common idea that some kids have no choice but to become criminals, a notion whose ambivalence The Wire explores in its fourth season. In his attempt to defend his reputation, he draws as much from the social analysis of The Wire, which he meticulously oversimplifies, as from the

${ }^{12}$ Alvarez devotes a whole section of his book to describe how successive Baltimore officials took exception to the The Wire's depiction of the city. “Mayor O'Malley to The Wire: Drop dead", in Alvarez, p. 210-15.

${ }^{13}$ See for instance James Poniewozik, "The Big Fat Year in Culture", in Profiles of Popular Culture: A Reader, ed. Ray Broadus Browne, Madison, The University of Wisconsin Press, 2005, p. 384 [p. 376-89]: "Best Social Criticism. The Wire. Ostensibly about cops and dealers, this series was really about how institutions use up and spit out their workers.” 
explanatory quality of factual life events. In fact, as the film unravels towards its ending, it gradually appears that its main point is to create a positive perspective on Barksdale. Significantly, The Avon Barksdale Story ends with a succession of three shots describing Barksdale as the victim of a crime tradition rather than as one of its beneficiaries (see Plates 1, 2, and 3).
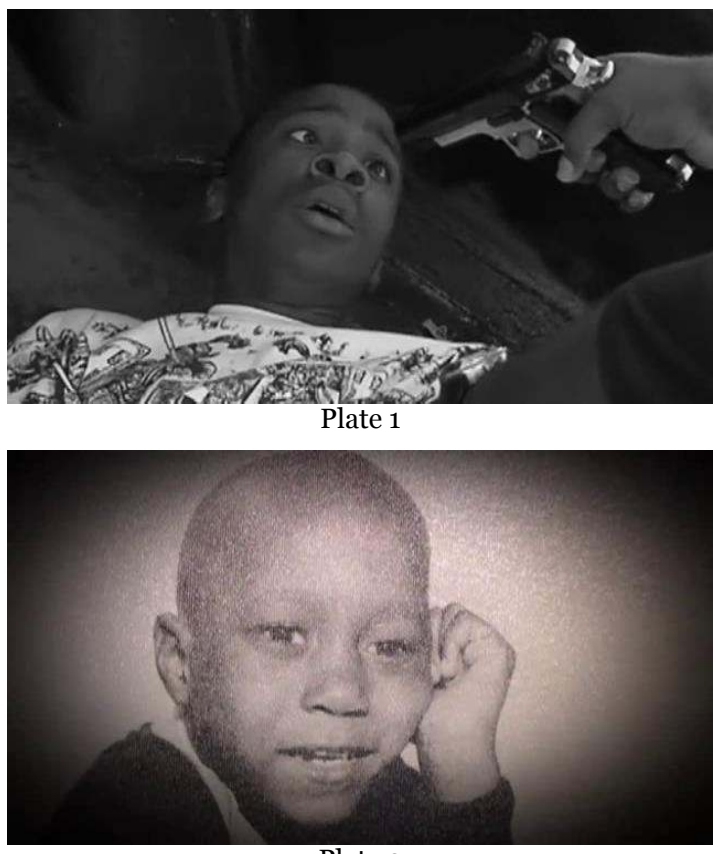

Plate 2

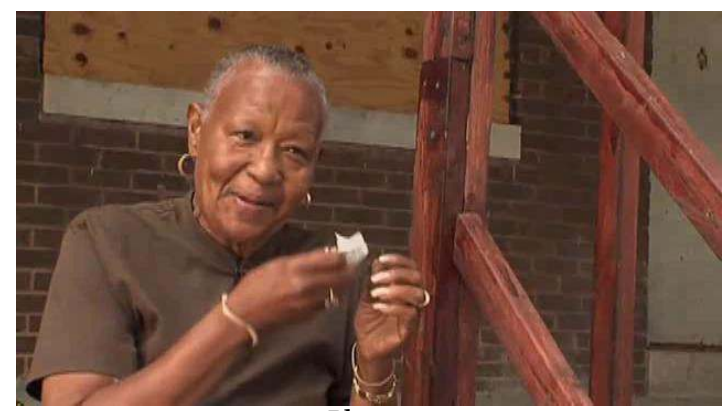

Plate 3 
The first one looks as if it were taken from The Wire. It is a high-angle close-up of a black kid's horrified face below a gun pointed at him. A documentary piece - a black-and-white ID photograph of Barksdale as a child - follows this shot. The third shot in the sequence is in colour. It shows Barksdale's mother declaring, by way of conclusion to the narrative, "he's my son". This comment invokes the pointlessness of accusing a kid of criminal deeds. A logic informing Barksdale's fate thus subtends the sequence. It conveys the notion that an early encounter with violence interfered with Barksdale's identity construction, and robbed the kid of his youth. Besides, the borrowing from the style of The Wire evinced in the first of the three shots implies that David Simon's series played a large part in distorting Barksdale's identity. The final comment by Barksdale's mother exposes the tale told in The Wire as a misconstruction, and suggests the series is responsible for turning her son into the gangster he never was in real life. As a result, it appears that the film's allusions to the series aim to engender confusion about the events of Barksdale's life, and to draw from fiction to rewrite history.

\section{The alternative make: resemblance and distortion}

A paradoxical combination of resemblance to and distortion from Simon's series informs the nature of The Avon Barksdale Story as an "alternative make". The film re-uses some of the trends found in The Wire. However, it makes them drift off from their original meaning and purpose. This warping perspective mainly concerns the vision of the American dream featured in The Wire, its satirical perspective on journalism, and even some specific characters in the show.

\section{A rags to riches story}

Critics have widely lauded the opening to the first episode of The Wire for the nonsensical perspective on the notion of equality of opportunity it features ${ }^{14}$. In this initial moment, McNulty hears the story of the recently murdered "Snot Boogie". Playing poker with other kids on the streets, Snot was allowed to grab the money and run away Friday night after Friday night. As the child reporting the anecdote to the detective has it, the other players would let him do so because "This is America, man". The punchline allegorises and satirises the widespread notion that, in the United States, everyone has a right to enter the success game, and therefore has a chance to thrive. To draw

${ }^{14}$ For a discussion of the scene's critical reception, see Jason P. Vest, The Wire, Deadwood, Homicide, and NYPD Blue: Violence is Power, Santa Barbara, Praeger, 2011, p. 179-83. The author's view that "the pilot episode's opening scene [... portrays] McNulty and the witness as fellow travelers in an urban pageant that prevents its participants from realizing the American dream" is particularly convincing (Vest, p. 183). 
on this famous critical trend in The Wire, The Avon Barksdale Story uses a similar "broken dream" perspective on Nathan. The copy, once again, fails to match the absurdity in the "Snot Boogie" anecdote that makes it so scathingly efficient. The film uses the concept of "rat race" America as the backdrop to Barksdale's childhood. The narrator explains that Nathan began as a paperboy who had to fight other paperboys to preserve and extend his delivery territory, and therefore to protect his job.

VOICE-OVER NARRATOR. Barksdale had bigger plans than being the king of pickpockets. He wanted to make more money. He became a paperboy too. But one paper round just wasn't enough. At a young age, he demonstrated his business savvy and leadership skills. Barksdale says he organised his own group of boys to muscle out competition and seize the territories of other paperboys over a wide area.

In the same sequence devoted to Barksdale's Bildung, the voice over describes a specific event as a "horrible tragedy". As an act of revenge for stealing his lunch, a man drove over Barksdale and smashed his leg. The narrator mentions that Barksdale had been stealing regularly from that same man. Nevertheless, the focus on the lunch suggests that hunger induced Barksdale to steal food. The sequence thus insists on Barksdale's "right to play" the criminal game. It is, however, a ridiculously melodramatic and hyperbolic reconstruction that falls short of The Wire's deluded observation that the "American dream" has lost its meaning, which is why Baltimore kids so absurdly misunderstand it.

\section{Exposing journalism}

Another unacknowledged borrowing concerns the series' critical perspective on the press. In The Wire's final season, David Simon directs his shafts at the Baltimore Sun newsroom, which he knows so well because of his former occupation. That journalists are so eager to believe McNulty's made up story of a bum-murdering serial killer casts a critical perspective on the gradual victory of tabloidization over investigative objectivity. As usual in the show, a methodical analysis of the causes for such a turn of events generates this angle. Like The Wire, The Avon Barksdale Story condemns the shortcomings of current journalistic practices. At the beginning of the film, the narrator puts the blame on media hype to explain Barksdale's current reputation.

VOICE-OVER NARRATOR. You know some people are uneasy that the real Barksdale is out of jail and walking the streets again. Perhaps they remember some of the things they heard and some of the things that Simon wrote about as a journalist. Maybe they remember some of the things documented on TV newscasts and in Simon's newspaper articles back in the 80 s when Barksdale was in power. 
Barksdale thus uses the sensationalist trend in contemporary journalism as sufficient evidence of his innocence. Nevertheless, he does not merely summon the alleged exculpating effect of criticising the press. Satirising news people even becomes an incriminating weapon when the film mentions Simon directly, to accuse him of peddling inaccuracies about the circumstances of Barksdale's conviction. At the beginning of the film, Barksdale explains that he warned the producers of The Wire "they'd better not cross the line". The threat educes that Simon is the butt of the criticism as the one responsible for destroying Barksdale's reputation. As a form of revenge, the film somehow turns Simon into a fictional character, and blurs the borderline between real and invented personae.

Ghosts from The Wire

The Avon Barksdale Story opens with a discussion of the differences and similarities between the characters in The Wire and their real-life counterparts. The exchange underlines that, without the docudrama, fans of the show would never realise how far Simon strays from reality. The Avon Barksdale Story, however, abounds in sequences that suggest similarity rather than difference. In fact, many of the "real" characters featured in The Avon Barksdale Story bear a striking resemblance to fictional characters in The Wire.

Those ghostly appearances of characters from The Wire evince Barksdale's desire to strike a clear-cut balance between fact and fiction, but also between good and evil, compared to the one the series foregrounds. The film, for instance, includes a sequence in which a man delivers a package containing heroin into a shop that serves as a front. The man's hairstyle and corpulence bring to mind the character of Eastside drug kingpin Proposition Joe (see Plates 4 and 5). 


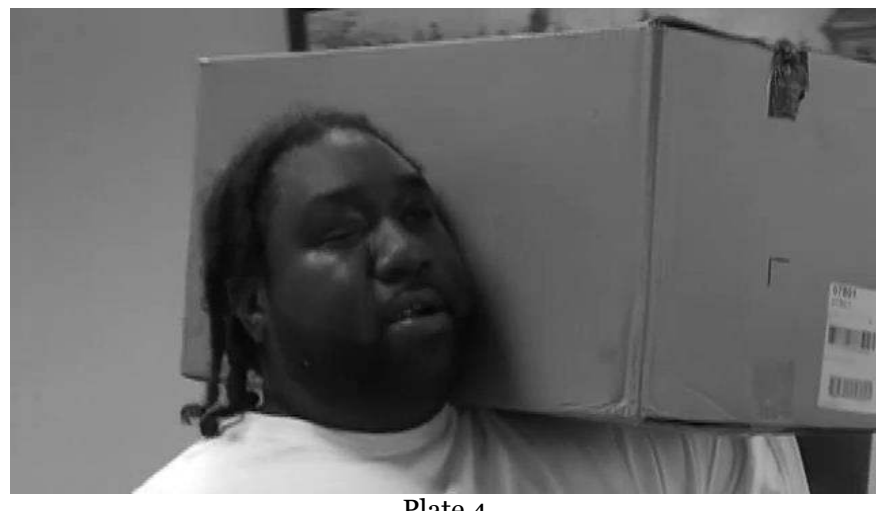

Plate 4

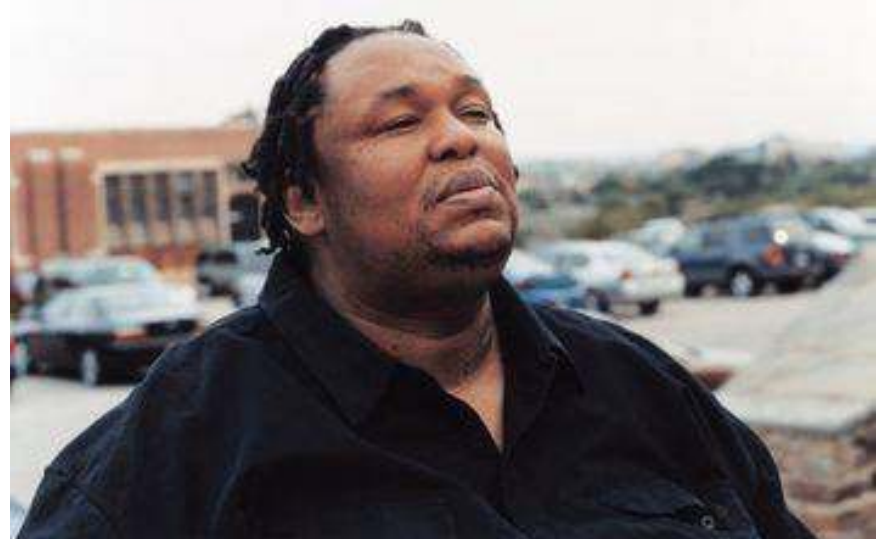

Plate 5

In the series, Prop Joe uses a cover as an appliance store operator for his drug dealing business. Joe also stands out as the one gangster who always favours peaceful solutions. By recasting him as a subordinate in the drug game, delivering the substance rather than selling or buying it, Barksdale shows that the hierarchy the series presents is unstable. He also claims that, in The Wire at least, it is a thin line between remaining a harmless pawn in a drug organisation and controlling it, and ironically underlines that Prop Joe, as an advocate of compromise, would never have achieved gang leadership in 
real life. This is in keeping with The Avon Barksdale Story's treatment of violence as just a rule in the street game.

This shifting of character identities conveys the idea that Barksdale could easily have had a different fate. The strategy consists in alleviating the guilt of the villains in the series by showing they could have been someone else. The stratagem is blatant when Barksdale applies it to himself. The authors of the film thus insinuate that David Simon could just as well have cast Barksdale as one of the good guys, rather than choosing his name for a Machiavellian, ruthless gangster. During its evocation of Barksdale's life in Baltimore as a kid, for instance, the film highlights that his mother had several jobs to earn a living. The commentary also specifies that she was a divorcee, and that her son had to look after his younger brothers. This presentation brings the young Barksdale close to character Michael Lee. Michael is one of the middle school pupils featured in Season 4 of The Wire, who had to endure similar conditions at home. In the series, the kid's family environment is one of the reasons for his becoming a protégé of drug kingpin Marlo Stanfield. By establishing a resemblance between the fictional character and Barksdale, the authors of the film seek to transfer the extenuating circumstances that apply to Michael onto the real-life Barksdale.

The technique recurs a few minutes later in the film. The voiceover relates that Nathan stole money from his boss with a few of his friends. By way of punishment, and above all as a way for the bosses to ensure the thieves would never rob them again, gangsters held the kids at gunpoint, threatening to shoot them, and locked them up in a basement in the company of "a vicious dog". This sequence looks like a reconstruction of real events. It connects two elements that seek to minimise the weight of Barksdale's crime. The first one is a reference to Omar Little. Omar is one of the most ambivalent characters in The Wire. He is a "stick-up man" who steals Robin-Hood like from bigger gangsters and stands out for his strict moral code of conduct. The second one is an allusion to Little Kevin, one of the kids in the Marlo Stanfield organisation. Marlo suspects Kevin of having informed the police. On mere suspicion, members of Marlo's crew force Kevin down into a basement and execute him. The "basement scare" episode in the film hints that Barksdale similarly committed childhood mistakes that could have cost him his life. The allusion also ranks Barksdale low in the Baltimore hierarchy of villains.

Finally, the film includes another echo when it depicts Nathan's passion for boxing. The character of Barksdale in the series shares this taste for the sport. The film's boxing gym sequences, however, operate a displacement to the character Dennis "Cutty" Wise in The Wire. A reference to a third person, haunting the same boxing gym as the real Barksdale, one Larry Middleton, triggers the shift of identities. 
VOICE-OVER NARRATOR. Larry Middleton is a former world class heavyweight boxer. In his prime, he ranked in the top 10. He fought the likes of Larry Holmes and Jimmy Ellis. [...] The man taught neighbourhood kids how to fight, but he lectured them about being good citizens and never using the skills he taught them the wrong way.

The narrator praises Middleton for finding redemption from life on the streets in sports. He also lauds him for offering salvation to kids from the streets by teaching them to unleash their violence in a cathartic way. Because of their kinship as boxing enthusiasts, the personalities of Barksdale and Middleton combine to evoke "Cutty". Cutty is one of the few characters in The Wire to achieve and promote "legit" life. He gives the kids an alternative to street violence in his self-made boxing gym.

Thanks to this complex network of reminiscences from The Wire, The Avon Barksdale Story indicts Simon for committing the glaring blunder of giving Barksdale's name to a character he was so different from. In so doing, the film insinuates there were so many other - and better - characters to whom he was closer. By acting on characters from the show, the film seeks to alter fact through fiction. In so doing, it brings out the series' specific way of making the diegetic overlap with the extradiegetic.

\section{The true Wire: fact through fiction}

\section{The anti-Manichean approach}

In an interview he gave to Nick Hornby, David Simon describes The Wire as a derivative of Greek tragedy adapted to postmodern times:

Much of our modern theatre seems rooted in the Shakespearean discovery of the modern mind. We are stealing instead from an earlier, less-traveled construct - the Greeks - lifting our thematic stance wholesale from Aeschylus, Sophocles, Euripides to create doomed and fated protagonists who confront a rigged game and their own mortality. The modern mind - particularly those of us in the West - finds such fatalism ancient and discomfiting, I think. We are a pretty selfactualised, self-worshipping crowd of postmoderns and the idea that for all of our wherewithal and discretionary income and leisure, we're still fated by indifferent gods, feels to us antiquated and superstitious. [...] But instead of the old gods, The Wire is a Greek tragedy in which the postmodern institutions are the Olympian forces. It's the police department, or the drug economy, or the political structures, or the school administration, or the macroeconomic forces that are throwing the lightning bolts and hitting people in the ass for no decent reason. In much of television, and in a good deal of our stage drama, individuals are often portrayed as rising above institutions to achieve catharsis. [... Because so much of television is about providing catharsis and redemption and the triumph of character, a drama in which postmodern 
institutions trump individuality and morality and justice seems different in some ways, I think ${ }^{15}$.

This perspective on the series accounts for its anti-Manicheism. Simon's characters are neither good nor bad, but fail to interpret a fate that overwhelms them. Describing this fate as institutional informs the nature of the catharsis the show produces. The Wire allows its spectators to vent their powerlessness in front of the system, but also to improve their knowledge of that system, and hopefully to minimise its most absurd sides.

On that point too, the derivative compares unfavourably to the original. As a result, the yearning to imitate the series that motivates The Avon Barksdale Story sets off the complexity of Simon's anatomy of contemporary American society. The lengthy critical speeches either Barksdale or the voice-over commentator give miss the visual elements that subtend critical discourse in The Wire. The first sequence after the credits of episode 1 , for instance, adds a specific visual treatment to the opening chat between McNulty and the kid from the projects about Snot Boogie's death. The sequence takes place in the courtroom. It conveys the notion that the rules of justice have changed under the influence of organised crime through the characters' exchanges of either domineering or resigned looks. Without saying a word, the actors conjure up the institutional fate Simon describes. This leads the spectators to understand that Barksdale has hired a false witness to fabricate the innocence of his nephew D'Angelo. At the beginning of the scene, shots of surveillance monitors embed CCTV footage within the picture. Such shots thus point to a superior power watching mere pawns in the game, and directing them to their fate. Yet The Wire does not only deal with the increasing presence of surveillance in contemporary societies. The programme also turns surveillance into the stylistic symbol of omnipresent institutions restricting the characters' freedom of movement and chance to achieve happiness ${ }^{16}$.

This visual composition is crucial for the show's construction of irony. It also participates in its constant awareness of the absurdity of postmodern life. The events depicted in The Wire elaborate a specific context that often takes explanatory value. Putting the series side by side with its pseudo-documentary counterpart also reveals this quality. Referring to sports as a way out of the vicious circle of the drug business is a case in point. Besides using boxing as a byword for channelling violence out, The Avon Barksdale Story includes a sequence in which basketball carries the same values. Before the

15 David Simon, “An interview with David Simon, by Nick Hornby", in Alvarez, p. 384-5 [p. 382-97].

${ }_{16}$ On this way of using surveillance in contemporary films and TV series, see Sébastien Lefait, Surveillance on Screen: Monitoring Contemporary Films and Television Programs, Lanham, The Scarecrow Press, 2013. 
sequence, the voice-over mentions "those who return to Baltimore roots in efforts to give back to the community". A view of kids on a basketball playground then illustrates one of those "efforts". The narrator describes the game as part of a "fund-raiser to benefit underprivileged youngsters". Besides, the sequence features views of cheering spectators alongside shots of the patrons supervising the game. Because it includes those ingredients, it remakes a similar moment featured at the end of Season 1 episode 9 in Simon's series. In The Wire, the basketball game opposes the West End and the East End teams. Barksdale coaches one side, and Proposition Joe the other. The match translates the rivalry between two gangs into a harmless contest. The scene also enriches the metaphor of criminal life as a "game" that pervades the series by showing the bosses and their subordinates insist on playing by the rules ${ }^{17}$. In this playful context, however, the bosses put high-stakes on defeating the opponent. They fret on the sides of the playground when the score evolves towards winning or losing. Rather than resorting to the cliché that sports activities are crucial to promote social peace, the series thus shows that it can just lead violence to go on in a different shape, and even stoke hatred rather than soothe it. The reference to basketball qualifies the reference to boxing, which The Wire presents in a positive light.

\section{The tragic dimension}

The Wire thus elicits Simon's awareness of the ambivalence of social solutions, whereas The Avon Barksdale Story systematically resorts to stereotypes and shortcuts. The film creates a onedimensional view of American society, which is remote from the "social tragedy" narrated in the series. Whereas Barksdale uses social determinism as an alibi for his past crimes and subsequently stages himself giving back to the community, Simon introduces a more analytical stance on the idea of social fate. Barksdale claims that, growing up in a criminal background as he did, he had to become a gangster. Yet his selected counterpart in The Wire, Michael Lee, has a more sinuous destiny. Michael's trajectory does not lead him straight out from his underprivileged background into life on the street, dealing drugs as a "corner boy". In Season 4 episode 4, two of the senior dealers he hangs around with, Snoop and Chris, predict Michael's future role as a junior drug salesman. A few minutes later in the episode, the spectators enter Michael's home with the character. The visit introduces unexpected causes for his fate, beyond the fact of living

${ }_{17}$ The Wire extends the widespread metaphor that the drug business is a game on many occasions throughout its five seasons, the most explicit one being the "chess" sequence in Season 1, episode 3. See Elizabeth Bonjean, "After the Towers Fell: Bodie Broadus and the Space of Memory", in The Wire: Urban Decay and American Television, ed. Tiffany Potter and CW. Marshall, New York, Continuum, 2009, p. 166-68 [p. 162-76]. 
in a crime-infested area. Once at home, Michael has trouble making his younger brother Bug do his homework, because the TV set blares out as their parents watch a programme they have "seen five times". Michael's family environment is one in which he is prone to grow up too fast, but also one in which watching TV leaves little room for intellectual activity. The brainwashing which extensive television consumption effects thus appears as the source of parental neglect. Although addiction to television is often presented as one of the consequences of unemployment, the sequence includes it as one of the possible causes that will eventually lead Michael to become a "corner boy". In The Wire, the reasons for Michael's predicament are undeniably more numerous and complex than the one Barksdale invokes for his own case in the documentary drama.

The tragic stature of The Wire also comes from its focus on the consequences of the character's actions, and especially on the high price of revenge. In The Avon Barksdale Story, comparatively, revenge is a justified action. As the voice-over explains, "sometimes dealers had to kill or be killed" and "taking a rival out before he took you out was just part of survival". One of the most interesting black-and-white sequences in the style of The Wire to appear in the docudrama illustrates this assertion. It shows one of Barksdale's rivals trying to ambush him, from preparation in a car to performance in the gangster's bar. The plan includes two young women used as decoys to numb the gangsters' suspicion before assaulting them. Members of Barksdale's crew manage to escape the ambush because their boss has cleverly placed the building under surveillance. The recent popularity of surveillance practices among the police forces, Barksdale comments, gave him the idea of using similar techniques for his own protection. At the end of the sequence, shots are fired from the building roof, and one of the young women is killed (see Plate 6).

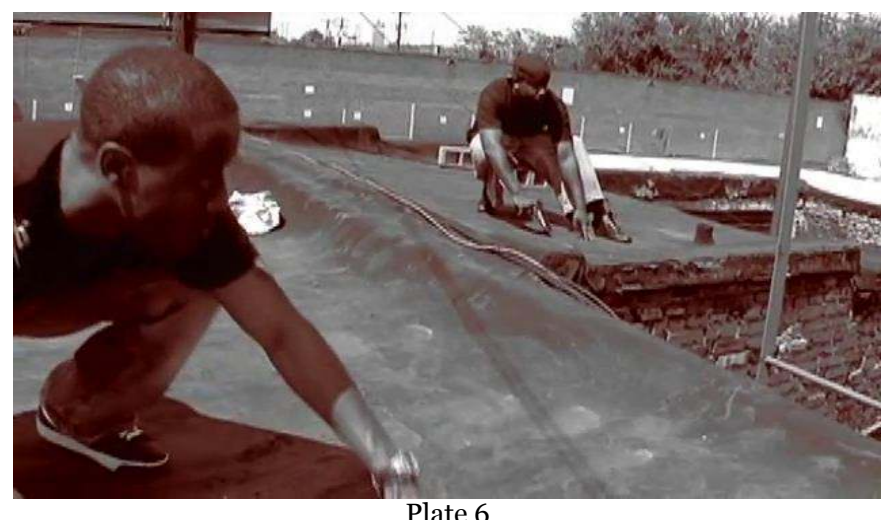

Plate 6 
The succession of events featured in the sequence is reminiscent of a similar moment in Season 3 episode 3. In this episode, Omar's plan to rob the drugs from Barksdale's stash also involves two female assistants. Before the raid, Omar explains his plan inside a car. The operation goes amiss because of the presence of surveillance forces - a member of Barksdale's crew was acting as a sentinel watching the building. This leads to massive shooting, with the Barksdale boys firing their guns from towering locations (see Plate 7). At the end of the sequence, friendly fire kills one of the young women.

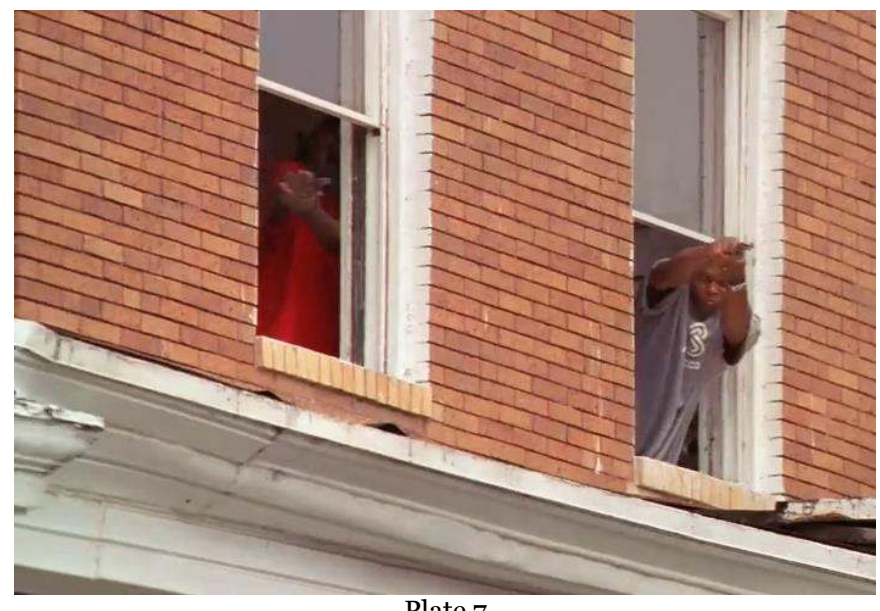

Plate 7

The similarities between this sequence and its equivalent in The Avon Barksdale Story are so numerous that questions arise about the motives for remaking it. The narrator's remark that the scene is reminiscent of gangster films with James Cagney is a weak attempt at stifling this feeling. The ideological reason for reproducing a sequence from the series is to reshuffle the good and evil cards dealt to the characters. In the docudrama, the attackers become the bad guys, and Barksdale appears to be merely defending himself. In the process, he sports his awareness of the innovative techniques the police use to track him down, which he implements himself by placing his hideout under surveillance. In the series, the sequence is a cog in Omar's retaliation for the murder of his lover by Avon's gang. It emphasises that vengeance comes at a bitter cost for Omar, who loses one of his friends. Comparatively, the film turns this perspective into a Manichean opposition of attackers and defendants. 
Why this rewriting of a sequence from The Wire has to be in the style of the series, however, is harder to explain. If Barksdale's aim was to depict the truth as opposed to the lies featured in The Wire, sticking to the documentary style would have been a more sensible option. A possible explanation to this quandary is that, by choosing to state the truth in the same visuals as those employed in Simon's programme, Barksdale endorses a form of fiction that is better suited to express reality than documentary is. The interest of the resemblance between The Avon Barksdale Story and The Wire thus lies in the visual echoes that ultimately emphasise the series' privileged bond to fact. While the stories told in The Wire may not all be genuine, the show depicts mechanisms driving contemporary American society that are all trueto-life. Whoever the characters are, whether real or fictional, and whatever they represent, the institutional cogs that propel them towards their fates are drawn from real life, and cannot be mistaken for fiction.

\section{The anatomy of a society}

In The Wire, the restrictions to freedom of choice receive specific attention. As the passage from Simon's interview quoted above shows, the tragedy in the series is that of a whole society that the institutional or ideological gods of political power, capitalism and greed direct from above. Thanks to this tragic quality, The Wire scrutinises contemporary American society, and establishes the ratio between the exercise of free will and its limitations under the weight of social conditions. Throughout this investigative process, the mechanisms that limit the range of action of individuals are in sharp focus. In particular, The Wire enhances the absurdity of present-day societies by showing characters who are eager to act to ensure a better future, yet whose initiatives are eventually to no avail. The ending to the first episode in the series shows this dead end. In the sequence, D'Angelo walks towards policemen surrounding a dead body, to find out it is Gaunt's. Even though he did not ask for such a murder, D'Angelo realises the witness who testified against him got killed on Avon's orders. A flashback shot precedes a high-angle view of D'Angelo walking away from the crime scene. It shows the aforesaid witness pointing his finger at D'Angelo offscreen. In retrospect, this gesture appears to have spelt Gaunt's death. Gaunt dies after a succession of events in which neither he who testified nor he who was testified against took part. The sequence thus presents one of the rules of the criminal game: snitches cannot be allowed to live.

In similar vein, The Wire often shows that the American land of hope has become a maze. The series depicts Baltimore as an absurd version of the country of opportunity. As opposed to the rags to riches pattern Barksdale applies to himself in the documentary drama, The 
Wire features the edifying story of Bubbles. Bubbles is a tramp and junkie who achieves newspaper fame and social redemption in the final season. His progress throughout owes nothing to the traditional ingredients of the American dream. Additionally, whereas The Avon Barksdale Story includes a "beautiful sights of Baltimore" promotional film, the series includes, in the opening sequence to the first episode, a gloomy representation of the city. Before and during McNulty's conversation with a witness about Snot Boogie's recent murder, the sequence's darkness conveys a feeling of oppression. Its down-to-theground approach roots the characters into the barren soil that gave them birth. Finally, the scene focuses on destitute areas and extensive policing. The notion of opportunity thus goes down from skyscraper high to slum level, and the series sets out to investigate the shadowy zones of dreamlike America.

In the world the series depicts, dreams, whatever their nature, are necessarily utopian. In Season 3, the tale of the "Hamsterdam" experiment establishes that point. The name refers to a specific zone in the West Baltimore projects where Major Colvin tests the beneficial effects of legalising drugs, unbeknownst to his superiors. From the point of view of the series, the experiment is a success. From that of the authorities, the experiment is a failure whose very existence they must conceal. In episode 3, a high-angle shot spanning the entire permissive area shows the experiment is doomed to abort (see Plate 8).

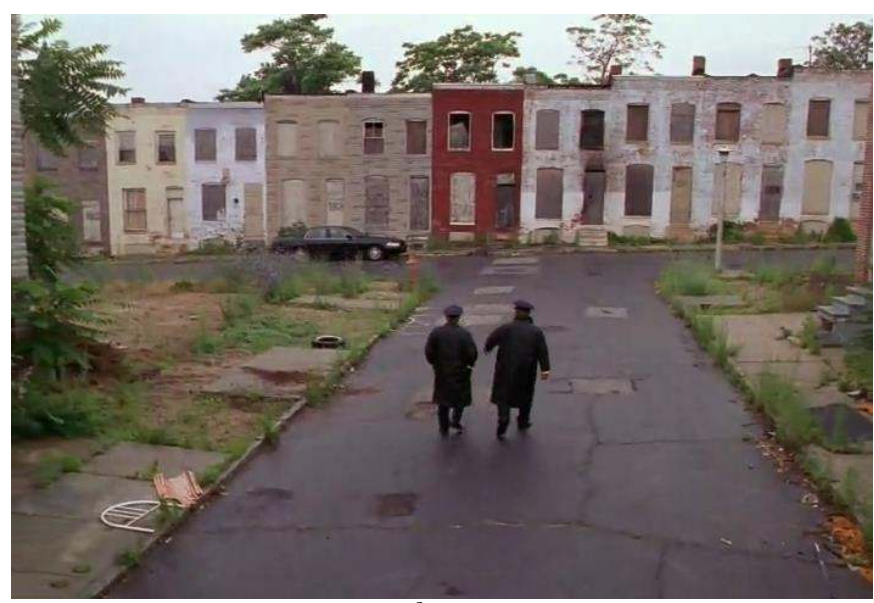

Plate 8

A view of the dreamer's look on Colvin's face follows, then a shot in which his colleague ironically mocks his idealism by making "you must have been smoking grass" gestures. 
The series thus devises a context in which dreams are not welcome because free will suffers institutional restrictions. Correlatively, the programme presents a society in which control, whether of oneself or of others, is a highly desired commodity. The visuals of The Wire convey and analyse the current quest for hypervision as a shortcut to power (see Plate 9). Even though the series' title focuses on auditory surveillance, The Wire includes many moments when visual control is correlated to authority. Such is the case in this shot from the pilot episode, where McNulty and Bunk enter the courtroom under the gaze of a CCTV camera, which suggests, at the series' outset, that police officers hold little power compared to judges and politicians.

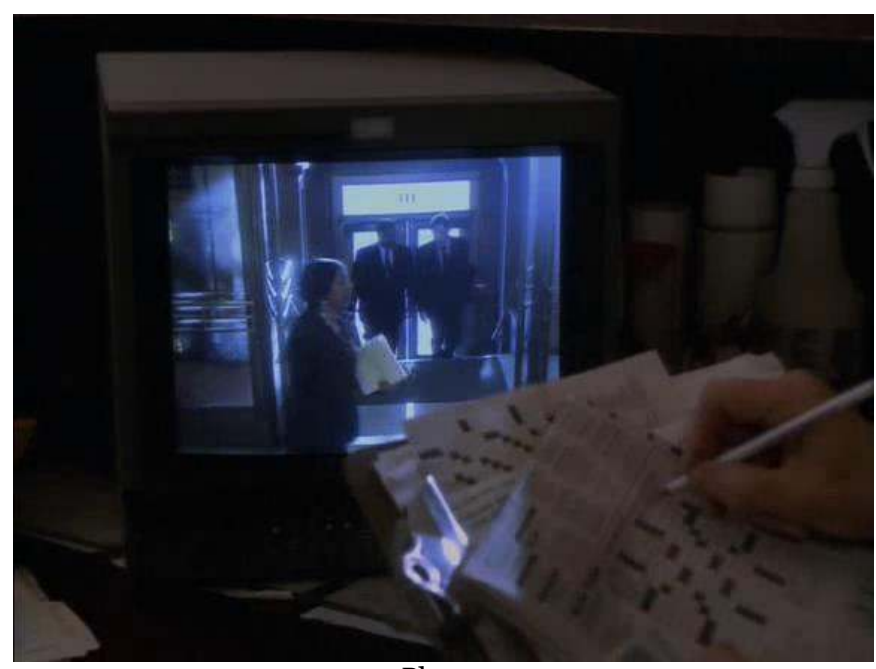

Plate 9

An urge to see what happens drives the characters, whether on the side of the police or on that of the gangsters. For them, it is essential to find out who does what and who is who. The network of references to surveillance that gives The Wire its name and meaning originates in the series' plan to make sense of the transparency craze. The Avon Barksdale Story includes a poor copy of this surveillance trend, which brings the analytical depth of the series to the surface. In the docudrama, Barksdale narrates how he eschewed the surveillance network the police put up to track him down. Agents were watching his crew from the top of a hospital, the employees of which were related to members of Barksdale's organisation. Consistently with the title Legends of the Unwired, the docudrama introduces characters who, unlike their counterparts from The Wire, are not only real, but also 
clever enough to escape monitoring. Then, in the ambush sequence mentioned above, a shot of the CCTV system covering Barksdale's stash is included (see Plate 10).

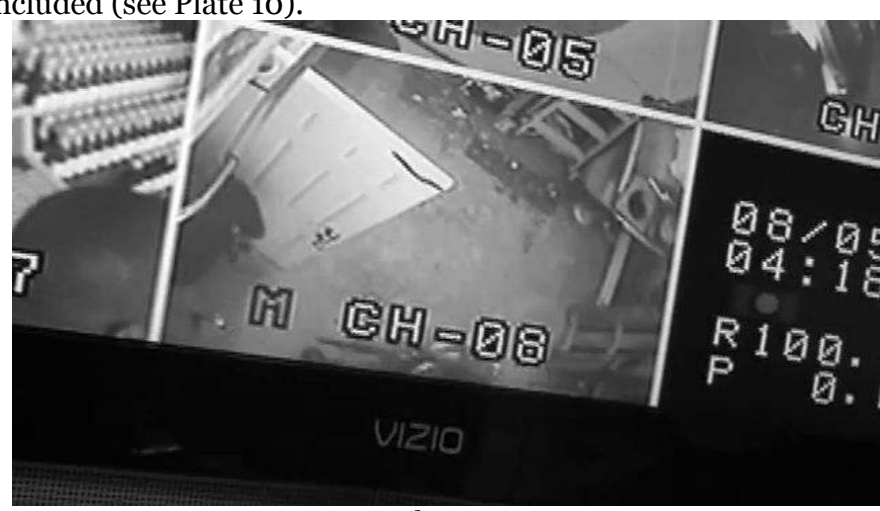

Plate 10

The docudrama thus insists on the high hopes placed in surveillance techniques, and on the high stakes of implementing them or breaking them.

In The Avon Barksdale Story, surveillance is a trick in a game of hide-and-seek. In The Wire, the surveillance trend supports the description of a dysfunctional society. In Season 1 episode 9, the attack on Barksdale by Omar's crew elicits this aspect. In the sequence, the layers of surveillance multiply up to the point where there is no knowing who is watching who and why. Because he supervises the whole murder raid, Omar acts as the centre of direct surveillance throughout the scene. Omar uses one of the pagers thanks to which Barksdale communicates with members of his gang to bring him out of his den. The contraption, which Barksdale utilises in the hope of escaping police surveillance, becomes a decoy, and ironically helps Omar locate him. The different kinds of gangsters Barksdale and Omar represent have in common a blind trust in surveillance. Their respective fates in the series prove that their faith in surveillance is in fact a tragic flaw. Throughout the five seasons of The Wire, it also appears that the police forces partake in the cult of monitoring techniques too. They are eager to obtain surveillance warrants, and they set up wiretaps that, they think, are indispensable for them to catch criminals. Despite the fact all those characters believe in the power of surveillance, some among them win while others lose. This outcome qualifies the idea that surveillance is an infallible way of achieving control. 
To follow up on the movement started in Season 1, which focused on the dysfunctions of both police institutions and gangster organisations, the final season of The Wire shows the collapse of investigative journalism ${ }^{18}$. The plot illustrates that the mission of the press - documenting reality and watching events objectively - has vanished. The Baltimore Sun sends a journalist among the homeless to exploit a craze created by the prowling presence of a tramp-murdering serial killer. The murderer, however, is a forgery. McNulty created this fictional character to garner extensive police forces and wiretap authorisations. Paradoxically, the invention of an imaginary character the police forces will have to look for is the premise to obtaining authorisation to surveil. Deluding the watchful eye of the police, and the not so vigilant eye of the press, is the price of surveillance permission.

By insisting on the loopholes and malfunctions of contemporary surveillance societies, however, The Wire manages to implement an analytical form of monitoring. By exposing fact through fiction, the series proves more efficient than actual surveillance. The Wire's surveillance principle discloses that some instruments of control have become dysfunctional. The series debunks the notion that surveillance is a byword for objectivity, and that it offers an unvarnished view of reality. On the contrary, The Avon Barksdale Story embodies the faith that using a documentary approach is enough to make narrated events become real. For all its claims to truthfulness, then, the docudrama fails to use the original Wire recipe, or just gets it wrong. The same as "sweded" movies"19 bring out the craftsmanship behind the films they remake in a crude way, The Avon Barksdale Story discloses why The Wire is closer to fact than it will ever be itself as a docudrama. The film's misunderstanding of The Wire elicits Simon's main achievement. The Wire is a "society watch" programme. A possible interpretation of the show's title suggests that it surveils a society to prevent it from going haywire. By using fictional situations that erase the details of reality, and thereby strip it down to the core, The Wire thus implements a new type of docudrama perspective: it effects surveillance through fiction.

\footnotetext{
${ }^{18}$ As Sherryl Vint notes, all five seasons in The Wire tackle malfunctioning structures: the series "shows the common dysfunction across [different] locations", namely "the police department, the drug-trafficking organization, political governance structures, the school system, and the media." Sherryl Vint, The Wire, Detroit, Wayne State University Press, 2013, p. 63 .

19 The phrase was coined by Jerry, a character in Michel Gondry's Be Kind - Rewind (2008). It refers to low-budget remakes of famous movies, often including a parodical vein. In Gondry's movie, Jerry rents out such films, and accounts for their long delivery schedule by claiming they have to come all the way from Sweden.
} 


\section{Bibliography}

Alvarez Rafael, The Wire: Truth Be Told, Edinburgh, Canongate, 2010.

ANDERSON Jeffrey, "Last Word: Nathan 'Bodie' Barksdale and Kenny Jackson tell their versions of Baltimore's street life in The Baltimore Chronicles: Legends of the Unwired", Baltimore City Paper, April 29 $9^{\text {th }}$, 2009. http://www2.citypaper.com/news/story.asp?id=17966\&p=4

(consulted August $3^{\text {rd }}$, 2012).

BonJEAN Elizabeth, "After the Towers Fell: Bodie Broadus and the Space of Memory", in The Wire: Urban Decay and American Television, ed. Tiffany Potter and CW. Marshall, New York, Continuum, 2009, p. 162-76.

Hight Craig and Jane RoscoE, Faking It: Mock-documentary and the Subversion of Factuality, Manchester, Manchester University Press, 2001.

LEFAIT Sébastien, Surveillance on Screen: Monitoring Contemporary Films and Television Programs, Lanham, The Scarecrow Press, 2013.

Poniewozik James, "The Big Fat Year in Culture", in Profiles of Popular Culture: A Reader, ed. Ray Broadus Browne, Madison, The University of Wisconsin Press, 2005, p. 376-89.

Simon David, "An interview with David Simon, by Nick Hornby”, in Rafael Alvarez, The Wire: Truth Be Told, Edinburgh, Canongate, 2010, p. 382-397.

Vest Jason P., The Wire, Deadwood, Homicide, and NYPD Blue: Violence is Power, Santa Barbara, Praeger, 2011.

VINT Sherryl, The Wire, Detroit, Wayne State University Press, 2013.

\section{The author}

Sébastien Lefait is Lecturer in English at the University of Corsica. He completed a PhD on Shakespeare and Orson Welles, in which he treated Welles's works as adaptations of and to Shakespeare's thought. Besides articles about films and about Shakespeare's plays, he has published articles about the new forms of film adaptation, which he considers as ways of re-producing meaning rather than just reproducing the original meaning of a literary work. His current research focuses on the use of surveillance in films and in TV series, in which he sees a socio-analytical instrument and an aesthetic tool. 